\title{
IUGR, lipid peroxidation, and calcium ATPase activity of maternal red blood cell ghosts
}

\author{
Glenys Malpica $^{1}$, Sandy Piñero ${ }^{1}$, Delia I Chiarello ${ }^{2}$, Fulgencio Proverbio ${ }^{1}$, Reinaldo Marín ${ }^{1}$ and Cilia Abad ${ }^{1 *}$ \\ ${ }^{1}$ Laboratorio de Bioenergética Celular, Centro de Biofísica y Bioquímica, Instituto Venezolano de Investigaciones Científicas (IVIC), Caracas, Venezuela \\ ${ }^{2}$ Cellular and Molecular Physiology Laboratory (CMPL), Division of Obstetrics and Gynaecology, School of Medicine, Faculty of Medicine, Pontificia Universidad Católica de Chile, \\ Santiago 8330024, Chile
}

\begin{abstract}
Intrauterine growth restriction (IUGR) leads to developmental disorders and deaths among neonates. There is strong evidence of oxidative stress in newborns, as well as in placenta of pregnant women with IUGR. Maternal red blood cells can be peroxidized as they pass through the placenta, which might induce alterations reducing their fluidity and, consequently, increasing their fragility to osmotic changes and inhibiting the activity of membrane-bound enzymes, such as the Ca-ATPase.
\end{abstract}

Objective: To determine osmotic fragility, lipid peroxidation levels and Ca-ATPase activity of red blood cell ghosts from pregnant women with intrauterine growth restriction in their third trimester of gestation.

Methodology: Venous blood was drawn from pregnant women, either with IUGR or controls. Osmotic fragility of the red cells, as well as lipid peroxidation (TBARS and conjugated dienes) and Ca-ATPase activity of their membranes were determined.

Results: It was found a higher level of osmotic fragility and lipid peroxidation, as well as a lower Ca-ATPase activity of red blood cells from the pregnant women with IUGR, as compared to control pregnant women.

Conclusion: There is a clear relationship between IUGR and higher levels of osmotic fragility and lipid peroxidation, as well as a lower Ca-ATPase activity of red blood cells.

\section{Introduction}

Normal fetal growth depends on several components: genetic growth potential of the fetus, ability of the placenta to transfer oxygen and nutrients, as well as capacity of the mother to deliver them to the placenta. Intrauterine growth restriction (IUGR) is defined as an estimated fetal weight at one point in time during pregnancy being at or below the 10th percentile for gestational age, and can be regarded as a failure of the fetus to reach his genetic growth potential. It is one of the major complications of pregnancy and it is associated with increased levels of morbidity and mortality in the neonate, as well as with several disorders including obesity, diabetes and heart disease in their adulthood. The reported incidence of IUGR ranges between 3-10\% [1].

IUGR is considered a multifactorial disease, which includes various fetal, placental and maternal aspects [2]. Maternal consequences of IUGR are usually related to a reduced uteroplacental blood flow and, consequently, to low oxygen-carrying capacity, a condition derived from a shallow trophoblast invasion during the first trimester of gestation. This condition results in a defective spiral artery remodeling [3], which leads to a rise of circulating free radicals. In fact, there is strong evidence of oxidative stress either in placenta as well as in newborns of gestational women with IUGR [1]. In this regard, Biri et al. found higher levels of malondialdehyde (MDA) and xanthine oxidase (XO) in maternal plasma, umbilical cord plasma, and placental tissues of patients with IUGR, as compared to a control group [4]. It has also been reported that oxidative DNA damage is increased in IUGR placenta [5]. Furthermore, other authors have shown increased levels of lipid peroxidation (TBARS, conjugated dienes and lipid peroxides) and decreased antioxidant capacity in serum of pregnant women with IUGR [6].
Once produced in the placenta, peroxidation by-products can attack circulating cells such as red blood cells, white blood cells and platelets, spreading the condition to distal tissues. Even more, oxidative damage of the red blood cells membranes, can lead to alterations in their fluidity, making them more vulnerable to osmotic changes, driving to an increased status of hemolysis. As a consequence, the resulting increment of hemoglobin and iron in the plasma, would result in the generation of substances as superoxide and hydroxyl radicals [7], triggering a cascade of oxidative events.

Alterations of cell plasma membranes may affect the structure and functionality of membrane bound enzymes, leading to inhibition of their activity. In this context, the aim of this study was to evaluate osmotic fragility of red blood cells of pregnant women with IUGR, as well as lipid peroxidation levels and Ca-ATPase activity of their plasma membranes.

\section{Materials and methods}

\section{Blood donors}

Ten women with IUGR (gestational age $37.4 \pm 1.12$ weeks) and ten gestational control (gestational age $38.00 \pm 0.41$ weeks) of the

Correspondence to: Dr. Cilia Abad, Laboratorio de Bioenergética Celular, Centro de Biofísica y Bioquímica, IVIC, Caracas 1020A, Venezuela, Tel: +58.212.504.1395; E-mail: clabad@gmail.com

Key words: IUGR, PMCA, lipid peroxidation, osmotic fragility, red blood cells Received: May 21, 2017; Accepted: June 06, 2017; Published: June 09, 2017 
Maternity Hospital "Concepción Palacios" in Caracas, participated in this study, which was carried-out in accordance with the ethical standards established by the Declaration of Helsinki. The study protocol was approved by the Institutional Review Board of the Maternity "Concepción Palacios" and by the Bioethic Committee of IVIC, and all participating women gave an informed signed consent. The gestational ages were estimated from the date of the last menstrual period, and confirmed by ultrasonography. All the pregnant women enrolled in the study were nulliparous, had similar demographic backgrounds, and belonged to urban populations of Caracas. The patient's age ranged between 18 and 30 years in both groups; none of the participating had a history of hypertension, diabetes, renal disease, or any other chronically medical illness, and none of them were taking any medication. Diagnosis of IUGR was determined by fetal ultrasound biometry (at least one during the first trimester), and Doppler ultrasound. Confirmation of the diagnosis was established through the infant's birth weight (gestational control, $3603.75 \pm 169.33$ $\mathrm{g}$ vs IUGR, $2348.8 \pm 202.36 \mathrm{~g} \mathrm{n}=10, \mathrm{p}<0.01$ ). The blood samples were obtained by venipuncture with the patients in lateral decubitus position and immediately transported to our laboratory on ice. An amount of $10 \mathrm{ml}$ of venous blood were collected into heparinized collection tubes from either gestational control or Pregnant women with IUGR. Each blood sample was centrifuged at $12,000 \mathrm{xg}$ for $1 \mathrm{~min}$ at $4^{\circ} \mathrm{C}$ and the buffy coat and the plasma were discarded. Hemoglobin-free red blood cell ghosts were prepared from the packed red cells, following the method of Heinz and Hoffman [8]. The ghosts were stored in a solution containing $17 \mathrm{mM}$ Tris- $\mathrm{HCl}$ and $0.1 \mathrm{mM}$ EDTA $\left(\mathrm{pH} 7.5\right.$ at $\left.0^{\circ} \mathrm{C}\right)$ until use, and were always utilized within the first 7 days of preparation.

\section{Osmotic Fragility of Red Blood Cells}

Osmotic fragility of red blood cells was determined as described elsewhere [9]. Briefly: $7.5 \mu$ l of previously washed red blood cells (50\% hematocrit) were added to $1.5 \mathrm{ml}$ of $\mathrm{NaCl}$ solutions with different osmolarities, starting with $150 \mathrm{mOsM}$. After 30 minutes at room temperature, the tubes were centrifuged at $16,000 \mathrm{xg}$ at $4^{\circ} \mathrm{C}$ for $2 \mathrm{~min}$ and then the absorbance of the supernatants, containing hemoglobin derived from the hemolyzed red blood cells, was measured at $540 \mathrm{~nm}$ in an Elisa Sunrise (Tecan) spectrophotometer. The percentage of hemolysis was calculated in each case in relation to the $100 \%$ hemolysis value, obtained hemolysing red blood cells in distilled water. The osmotic fragility curve was fitted with the Boltzmann equation for sigmoidal fitting, using Origin ${ }^{\circ}$. The osmolar concentrations producing $50 \%$ hemolysis of the red blood cells, utilized as a parameter of osmotic fragility, was defined as $\mathrm{OS}_{50}$ and was calculated from the hemolysis curves. All the determinations were run in quadruplicate.

\section{ATPase assays}

The Ca-ATPase activity of red blood cell ghosts was determined as described elsewhere [9]. The enzymatic reaction was carried out at $37^{\circ} \mathrm{C}, \mathrm{pH} 7,5$, with $\sim 1.5 \mathrm{mg}$ protein/ml. The media contained (final concentrations): $2 \mathrm{mM}$ Tris-ATP; $3 \mathrm{mM} \mathrm{MgCl} ; 0.1 \mathrm{mM}$ ouabain; 0.1 mM EGTA; $50 \mathrm{mM}$ Tris- $\mathrm{HCl}$ (pH 7.4 at $37^{\circ} \mathrm{C}$ ); $15 \mathrm{mM} \mathrm{KCl}, 80 \mathrm{mM}$ $\mathrm{NaCl}$; either in the absence or in the presence of $0.1 \mu \mathrm{M}$ calmodulin and $10 \mu \mathrm{M}$ free calcium. The results were calculated as the difference between the amount of phosphate liberated in tubes containing $\mathrm{Ca}^{2+}$ minus that liberated in tubes without $\mathrm{Ca}^{2+}$, and are expressed as nanomoles of inorganic phosphate liberated per milligram of protein per minute, after subtraction of a blank run in parallel without the membrane suspension, which was added after stopping the reaction.

\section{Lipid peroxidation measurements}

The amount of lipid peroxidation of red blood cell ghosts was estimated by measuring both: TBARS and conjugated dienes as mentioned elsewhere [9]. The TBARS values were calculated using a malondialdehyde (MDA) standard curve, prepared by acid hydrolysis of 1,1,3,3- tetramethoxypropane. To determine the conjugated dienes, total lipids were extracted from red blood cells ghosts and the dienes were estimated by reading the total lipid extracts in hexane at $233 \mathrm{~nm}$ in a spectrophotometer and calculated using an extinction coefficient of $27,000 \mathrm{M}^{-1} \mathrm{~cm}^{-1}$. The conjugated dienes are expressed as nmol hydroperoxides/mg lipids.

Chemiluminescence generated in cell-free systems: $\mathrm{H}_{2} \mathrm{O}_{2}$-induced chemiluminescence. Hydrogen peroxide was diluted with a phosphatebuffered saline solution (PBS; $10 \mathrm{mM} \mathrm{KH}_{2} \mathrm{PO}_{4}$, and $150 \mathrm{mM} \mathrm{NaCl}, \mathrm{pH}$ 7.4). An aliquot of $50 \mu \mathrm{l}$ of $\mathrm{H}_{2} \mathrm{O}_{2}(2 \mathrm{mM}$, final concentration) (Sigma Chemical Co., St. Louis, MO, USA), $50 \mu$ l luminol (5-amino-2,3dihydro-1,4-phthalazinedione, Aldrich, Milwaukee, MN, USA) (450 $\mu \mathrm{M}$, prepared daily with $\mathrm{PBS}$ ) and $4 \mathrm{mM} \mathrm{NaOH}$, final concentration, was mixed with either $10 \mu \mathrm{l}$ of blood plasma (from gestational control and IUGR) or $10 \mu \mathrm{l}$ of PBS as a blank [10]. In the enhanced-CL luminol assay light is emitted when luminol reacts with ROS [11]. The generated chemiluminescence $(\mathrm{CL})$ at $37^{\circ} \mathrm{C}$ was measured continuously for 50 seconds in a Luminoskan Ascent Luminometer (ThermoLabsystems, Finland), in a 96-well Thermo Lab systems microliter plate. The luminescence was expressed in relative light units (RLU).

\section{Statistical analysis}

Comparisons between treatment conditions were assessed by oneway ANOVA with the post hoc analysis with the Student-NewmanKeuls test. All results are expressed as means \pm S.E. and (n) represents the number of experiments performed with different preparations. In all cases, the Ca-ATPase activity was calculated from paired data. A p-value $\leq 0.05$ was accepted as statistically significant.

\section{Results}

Increased levels of oxidative stress have been described in serum of pregnant women with IUGR [6]. In fact, the blood plasma levels of TBARS from Pregnant women with IUGR were significantly increased as compared with control pregnant women (gestational control, $2.38 \pm 0.17 \mathrm{nmoles} \mathrm{MDA} / \mathrm{ml}$ plasma vs IUGR, $5.32 \pm 0.49 \mathrm{nmoles} \mathrm{MDA} /$ ml plasma, $\mathrm{n}=10, \mathrm{p}<0.001$ ).

As can be seen in Figure 1, the emitted luminescence during the enhanced-CL luminol assay by blood plasma of pregnant women with IUGR, was significantly greater than that by plasma of gestational controls. This indicates that pregnant women with IUGR, as compared with gestational controls, have a reduced ability to depurate hydroxyl radicals.

The higher levels of TBARS in the blood plasma of pregnant women with IUGR could be an indication that the blood cells from these women are also peroxidized. As shown in Table 1, the level of lipid peroxidation of red blood cell ghosts, determined either by measuring their levels of TBARS or their conjugated dienes, is higher for pregnant women with IUGR as compared to gestational control women.

Increased osmotic fragility is one of the consequences of exposure of human red blood cells to oxygen radicals [12]. In fact, we found that red blood cells from pregnant women with IUGR were more sensitive to an osmotic shock than those from gestational control women, as indicated by their higher $\mathrm{OS}_{50}$ (Figure 2). 
As shown in Table 2, the Ca-ATPase activity of red blood cells ghosts of pregnant women with IUGR was found to be lower than that of control pregnant women. In order to evaluate the possible relationship between the Ca-ATPase activity and the levels of lipid peroxidation of red cell membranes, the ATPase activity was plotted as a function of the level of TBARS and conjugated dienes of the red cell ghosts. This analysis (Figure 3) clearly indicates the existence of an inverse linear relationship between the Ca-ATPase activity and the

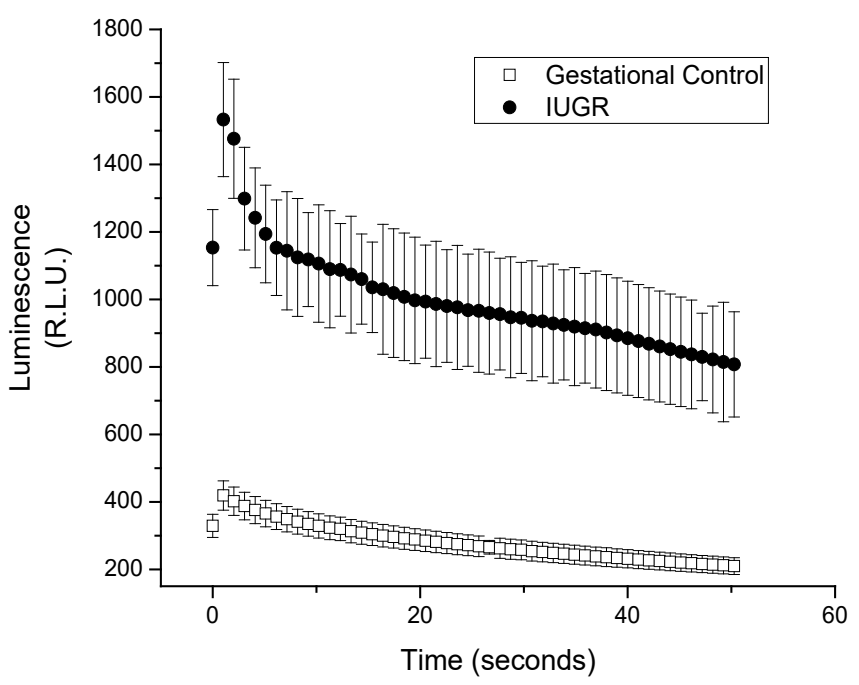

Figure 1. Chemiluminescence of luminol $\mathrm{CL}$, in the presence of blood plasma from uncomplicated or Pregnant women with IUGR. Values are expressed as mean \pm S.E., for $\mathrm{n}=10$.

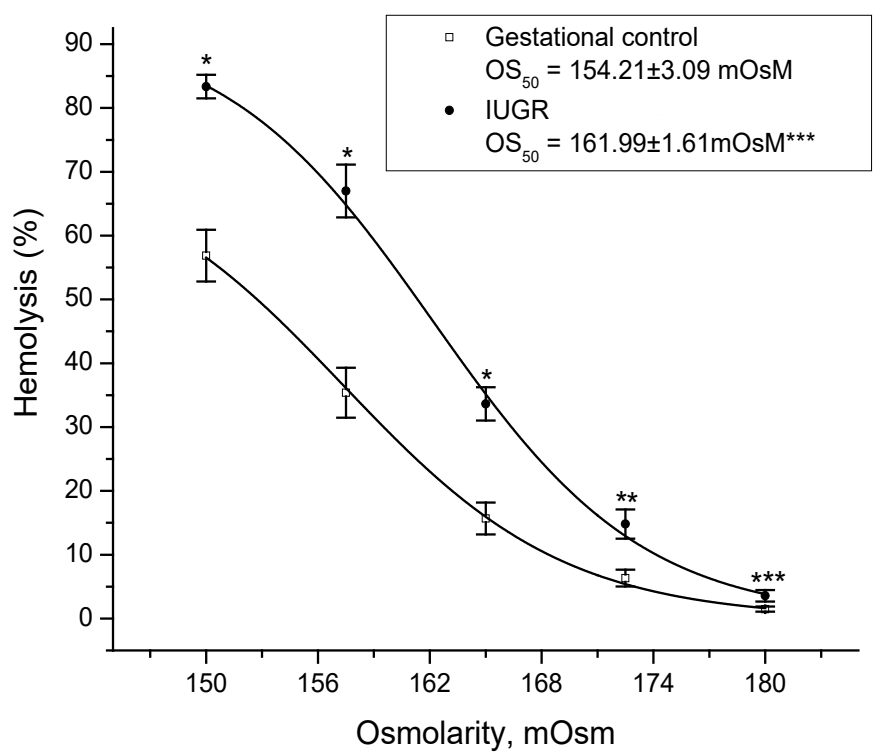

Figure 2. Osmotic fragility of red blood cells from uncomplicated or pregnant women with IUGR. Values are expressed as mean \pm S.E., for $\mathrm{n}=12 .{ }^{*} p<0.0001$ or $* * p<0.01$ or $* * *$ $p<0.05$ vs gestational control.

Table 1. Conjugated dienes and TBARS of red blood cells ghosts from IUGR or Gestational control women

\begin{tabular}{|c|c|c|}
\hline & Conjugated dienes $^{(\mathbf{a})}$ & TBARS $^{(\mathbf{b})}$ \\
\hline Gestational Control & $3.71 \pm 0.29$ & $0.28 \pm 0.02$ \\
\hline IUGR & $6.84 \pm 0,51^{*}$ & $0.87 \pm 0.04^{*}$ \\
\hline
\end{tabular}

(a) $\mu$ moles hydroperoxides/mg lipids; ${ }^{(b)}$ nmoles malondialdehyde/mg protein.

Values are expressed as mean \pm S.E., for $\mathrm{n}=10 .{ }^{*} p<0.001$ vs gestational control
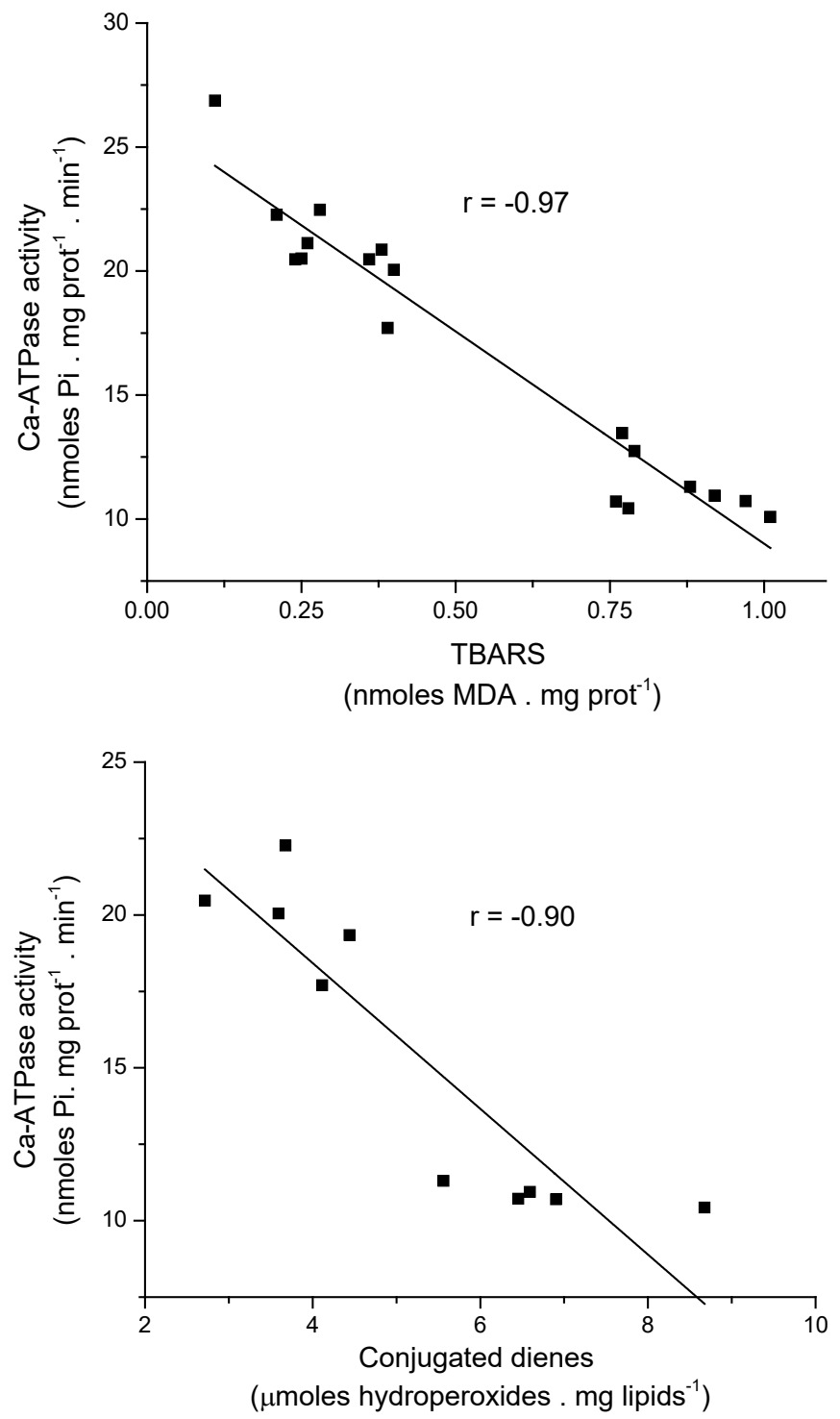

Figure 3. Relationship between level of lipid peroxidation and Ca-ATPase activity of red blood cells ghosts from uncomplicated and pregnant women with IUGR. (Data taken from Tables III and IV).

Table 2. Ca- ATPase activities of red blood cells ghosts from IUGR or Gestational control women.

\begin{tabular}{|c|c|}
\hline & $\begin{array}{c}\text { Ca-ATPase activity } \\
\text { nmoles Pi/mg prot . min }\end{array}$ \\
\hline Gestational control & $21.12 \pm 1.30$ \\
\hline IUGR & $11.63 \pm 0.49^{*}$ \\
\hline
\end{tabular}

The Ca-ATPase activity was assayed in the presence of $0.5 \mu \mathrm{M}$ calmodulin. Values are expressed as mean \pm S.E., for $\mathrm{n}=10$. ${ }^{*} p<0.001$ vs gestational control

level of lipid peroxidation of the red cell ghosts, either determined by TBARS $(r=-0.97)$ or conjugated dienes $(r=-0.90)$.

\section{Discussion}

Many factors, including maternal, fetal and placental disorders, can influence fetal growth [13]. A diminished fetal growth is generally accompanied with a decrease of important substances for the body, such as glucose and $\mathrm{Ca}^{2+}$ [14], amino acids [15] and fatty acids [16]. In this regard, it has been demonstrated that IUGR is associated with 
a lower activity and expression of placental transport systems for essential amino acids, such as taurine, leucine and cationic amino acids [13]. Besides, it has also been shown that the reduced fetal weight that characterizes this condition is related to an incorrect adjustment of the placenta and poor development of the villi, conditions that lead to placental hypoxia [17] and consequently to low utero-placental perfusion and maternal-fetal transport of oxygen and nutrients [18]. The insufficient quantity of oxygen supplied to the placental cells derived from the hypoxia condition, can lead to the generation of free radicals, promoting oxidative stress [19] and cell damage. Through the placenta, the oxidative stress can reach the circulating blood, spreading the condition to other tissues of the organism [20].

The placenta can be an important source of oxidative stress during pregnancy, secreting polyunsaturated peroxidized fatty acids into the maternal circulation. However, this condition is normally neutralized by the body, increasing its antioxidant defenses [21]. Pregnant women with IUGR has been shown to develop increased levels of oxidative stress in placenta [5] and amniotic fluid [22], as well as a decreased quantity of enzymatic antioxidants in their cord blood [1], as compared to control pregnant women. Karowicz-Bilinska et al. [6] found an elevated oxidative stress in blood serum of pregnant women with IUGR and a decreased total antioxidant capacity of the serum as compared to healthy pregnant women. This is in agreement with our results showing increased levels of TBARS (Table 1) and reduced antioxidant capacity (Figure 1) in women with IUGR.

Elevated levels of plasma lipid peroxidation can spread the oxidative stress through the entire organism. Even more, the increased level of lipid peroxidation we found for red blood cells ghosts from IUGR women (Table 1), may result in their lysis, with a consequent release of iron into the plasma which, in turn, could catalyze the formation of highly damaging species, including superoxide and hydroxyl radicals [23], which would amplify the oxidative damage.

Cell fragility is strongly dependent on its intrinsic membrane properties and it is increased by reduction of the membrane fluidity [12], as it has been shown for red blood cells of preeclamptic women with increased levels of lipid peroxidation [24]. In this particular, we found an increased osmotic fragility of red blood cells of pregnant women with IUGR (Figure 2), a condition that can be explained considering a lowered capacity of deformability of their cell membranes, induced by the structural changes and their consequent reduced fluidity derived from their increased level of lipid peroxidation. In this particular, it has been found an increased level of lipid peroxidation in cord blood of babies from pregnant women with IUGR $[1,25]$ and, even more, red blood cell membrane deformability appears to be increased in preterm infants [26].

The activity of membrane-bound enzymes dependent on proteinlipid interactions, such as the calcium adenosine triphosphatase (Ca-ATPase) of cell membranes are inhibited by increased levels of lipid peroxidation of the membranes [9]. In this sense, we found the same behavior: a lowered activity of the Ca-ATPase of red blood cell membranes of pregnant women with intrauterine growth restriction (Table 2).

Pregnancies complicated by IUGR are associated with fetal and neonatal hypocalcemia and signs of reduced bone mineralization in childhood [14]. Even when the causes of these alterations are not clear, it is known that $\mathrm{Ca}^{2+}$ serum regulation in the fetus is complex and depends on both: placental $\mathrm{Ca}^{2+}$ transportation, and mother's $\mathrm{Ca}^{2+}$ homeostasis [14,27]. In this regard, transport of placental calcium in pregnancies complicated by IUGR, has been found to be decreased in an IUGR model in rats [28]. Interestingly, we have found in preliminary experiments (unpublished data) a decreased Ca-ATPase activity in both, basal (BM) and microvillous (MVM), membranes of syncytiotrophoblast from human placenta of pregnant women with intrauterine growth restriction.

\section{Acknowledgements}

This research was supported in part by grant No. H9/181/R427, Project 96350, from the World Health Organization and by grant from FONACIT - Venezuela No. F-2005000222. The authors wish to thank Dr. Sonia Sosa, head of the "Servicio Prenatal", Maternity Hospital "Concepción Palacios" for her collaboration during this study.

\section{Declaration of interest}

The authors report no conflicts of interest. The authors alone are responsible for the content and writing of this paper.

\section{References}

1. Hracsko Z, Orvos H, Novak Z, Pal A, Varga IS (2008) Evaluation of oxidative stress markers in neonates with intra-uterine growth retardation. Redox Rep 13: 11-16. [Crossref]

2. Miller J, Turan S, Baschat AA (2008) Fetal growth restriction. Semin Perinatol 32: 274-280. [Crossref]

3. Kaufmann P, Black S, Huppertz B (2003) Endovascular trophoblast invasion implications for the pathogenesis of intrauterine growth retardation and preeclampsia. Biol Reprod 69: 1-7. [Crossref]

4. Biri A, Bozkurt N, Turp A, Kavutcu M, Himmetoglu O et al. (2007) Role of oxidative stress in intrauterine growth restriction. Gynecol Obstet Invest 64: 187-192. [Crossref]

5. Takagi Y, Nikaido T, Toki T, Kita N, Kanai M et al. (2004) Levels of oxidative stress and redox-related molecules in the placenta in preeclampsia and fetal growth restriction. Virchows Arch 444: 49-55. [Crossref]

6. Karowicz-Bilinska A, Kedziora-Kornatowska K and Bartosz G. (2007) Indices of oxidative stress in pregnancy with fetal growth restriction. Free Radic Res 41: 870873. [Crossref]

7. Halliwell B, Gutteridge JM (1990) Role of free radicals and catalytic metal ions in human disease: an overview. Methods Enzymol 186: 1-85. [Crossref]

8. Heinz E, Hoffman JF (1965) Phosphate Incorporation And Na, K-Atpase Activity In Human Red Blood Cell Ghosts. J Cell Comp Physiol 65: 31-43. [Crossref]

9. Abad C, Teppa-Garrán A, Proverbio T, Piñero S, Proverbio F et al. (2005) Effect of magnesium sulfate on the calcium-stimulated adenosine triphosphatase activity and lipid peroxidation of red blood cell membranes from preeclamptic women. Biochem Pharmacol 70: 1634-1641. [Crossref]

10. Rose AL, Waite TD (2001) Chemiluminescence of luminol in the presence of iron(II) and oxygen: oxidation mechanism and implications for its analytical use. Anal Chem 73: 5909-5920. [Crossref]

11. Murphy ME, Sies H (1990) Visible-range low-level chemiluminescence in biologica systems. Methods Enzymol 186: 595-610. [Crossref]

12. Srour, Bilto YY, Juma M, Irhimeh MR (2000) Exposure of human erythrocytes to oxygen radicals causes loss of deformability, increased osmotic fragility, lipid peroxidation and protein degradation. Clin Hemorheol Microcirc 23: 13-21. [Crossref]

13. Cetin I, Foidart JM, Miozzo M, Raun T, Jansson T et al. (2004) Fetal growth restriction a workshop report. Placenta 25: 753-757.

14. Strid H1, Bucht E, Jansson T, Wennergren M, Powell TL (2003) ATP dependent $\mathrm{Ca}^{2+}$ transport across basal membrane of human syncytiotrophoblast in pregnancies complicated by intrauterine growth restriction or diabetes. Placenta 24: 445-452. [Crossref]

15. Regnault TR, Friedman JE, Wilkening RB, Anthony RV, Hay WW (2005) Fetoplacental transport and utilization of amino acids in IUGR--a review. Placenta 26 Suppl A: S5262. [Crossref]

16. Herrera E, Ortega-Senovilla H. (2014) Lipid metabolism during pregnancy and its implications for fetal growth. Curr Pharm Biotechnol 15: 24-31. [Crossref] 
17. Arroyo JA, Winn VD (2008) Vasculogenesis and angiogenesis in the IUGR placenta. Semin Perinatol 32: 172-177. [Crossref]

18. Laurin J, Lingman G, Marsál K, Persson PH (1987) Fetal blood flow in pregnancies complicated by intrauterine growth retardation. Obstet Gynecol 69: 895-902. [Crossref]

19. Behn C, Araneda OF, Llanos AJ, Celedón G, González G (2007) Hypoxia-related lipid peroxidation: evidences, implications and approaches. Respir Physiol Neurobiol 158: 143-150. [Crossref]

20. Sotnikova LG, Naumov AV, Kuznetsova VA (1986) [Significance of various indicators of lipid peroxidation of erythrocyte membranes in late pregnancy toxemia]. Akush Ginekol (Mosk): 20-22. [Crossref]

21. Sikkema JM, van Rijn BB, Franx A, Bruinse HW, de Roos R et al. (2001) Placental superoxide is increased in pre-eclampsia. Placenta 22: 304-308. [Crossref]

22. Longini M, Perrone S, Kenanidis A, Vezzosi P, Marzocchi B et al. (2005) Isoprostanes in amniotic fluid: a predictive marker for fetal growth restriction in pregnancy. Free Radic Biol Med 38: 1537-1541. [Crossref]
23. Halliwell B, Gutteridge JMC (1989) Free Radicals in Biology and Medicine. Oxford, U.K.: Clarendon Press 1-543 p.

24. Abad C, Carrasco MJ, Piñero S, Delgado E, Chiarello DI et al (2010) Effect of magnesium sulfate on the osmotic fragility and lipid peroxidation of intact red blood cells from pregnant women with severe preeclampsia. Hypertens Pregnancy 29: 38-53. [Crossref]

25. Leduc L, Delvin E, Ouellet A, Garofalo C, Grenier E et al. (2011) Oxidized low-density lipoproteins in cord blood from neonates with intra-uterine growth restriction. Eur J Obstet Gynecol Reprod Biol 156: 46-49. [Crossref]

26. Linderkamp O, Kiau U, Ruef P (1997) Cellular and membrane deformability of red blood cells in preterm infants with and without growth retardation. Clin Hemorheol Microcirc 17: 279-283. [Crossref]

27. Cetin I, Marconi AM, Baggiani AM, Buscaglia M, Pardi G et al. (1995) In vivo placental transport of glycine and leucine in human pregnancies. Pediatr Res 37: 571575. [Crossref]

28. Mughal MZ, Ross R, Tsang RC (1989) Clearance of calcium across in situ perfused placentas of intrauterine growth-retarded rat fetuses. Pediatr Res 25: 420-422. [Crossref]

Copyright: @2017 Malpica G. This is an open-access article distributed under the terms of the Creative Commons Attribution License, which permits unrestricted use, distribution, and reproduction in any medium, provided the original author and source are credited. 